\title{
Archaeological Thinking and Practice in Maritime Archaeology
}

\author{
Panagiota Markoulaki
}

Published online: 14 April 2009

(C) Springer Science+Business Media, LLC 2009

Maritime archaeology remained for many years "misunderstood", a "photogenic" discipline that has inspired numerous popular accounts as opposed to research publications (Bass 1980, pp. 137-152). Although maritime archaeology is no longer a 'nascent' discipline (Gibbins and Adams 2001, pp. 279-291), it is still considered as a relatively young field that is too technical and lacks theoretical orientation (e.g. Hocker 2004, pp. 1-11). While these criticisms remain a continuous concern in scholarly work, the increasing demand for core skills in commercial archaeology and research oriented agendas have inevitably led to the need for integrating job-related training with academic research in higher education courses. Such integration, however, can easily focus on the teaching of the methods of archaeological analysis and miss the scope of education which should be the teaching of methodology which is theoretically oriented composes the most important part of archaeological epistemology. While archaeological methods compose an integral part of archaeological practice, methodology comprises an integral part of archaeological philosophy. Through education, a student should expect to be provided with the necessary knowledge in the discipline, as well as with an understanding of the way in which archaeological practice fits into archaeological methodology. It is in my view that such a pedagogical approach can better develop the students' archaeological thinking which I consider as the most important characteristic of a well-grounded individual who can be further engaged with research and/or professional training in the discipline.

\section{References}

Bass GF (1980) Marine archaeology: a misunderstood science. In: Borgese EM, Ginsburg N (eds) Ocean Yearbook 2. University of Chicago Press, Chicago, pp 137-152

Gibbins D, Adams J (2001) Shipwrecks and maritime archaeology. World Archaeol 32(3):279-291

Hocker KM (2004) Shipbuilding: philosophy, practice, and research. In: Hocker FM, Ward CA (eds) The philosophy of shipbuilding-conceptual approaches to the study of wooden ships. Texas A\&M University Press, College Station, pp 1-11

P. Markoulaki ( $₫)$

Trent and Peak Archaeology, University of Nottingham, University Park, Nottingham NG7 2RD, UK

e-mail: panagiota.markoulaki@nottingham.ac.uk 